2-I-2-7 Forward Maskingの応用（１）－騒音の許容基隼について－

1.はじめに。

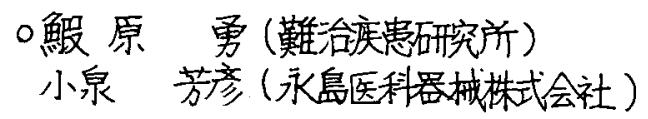

動いている゙きこえ,の状態を精雄に記 述することはさすずかしいことである。生体 を対象にした聴覚度労試験成績が、バラッ キの大きい理由は ぞの上ミらに耳年小 骨筋反射の個体差が絡んでいるからとされ てきた。

これらの諾難問を解消しさらに一つ 一つの耳について肌理細が心遣いのでき 点 る記述法として 著者らけ Forward Masking を応用した方法を考案し 騷音による耳の 健康障害に対方了許容基睤の推定を試みた ので、午の方法および結果の概要について 報告し，大方のジ批判を仰ぎたいと惟う。

2. 騷音の許容基準の求め方と测り方。

Forw ard Masking の経過の分類

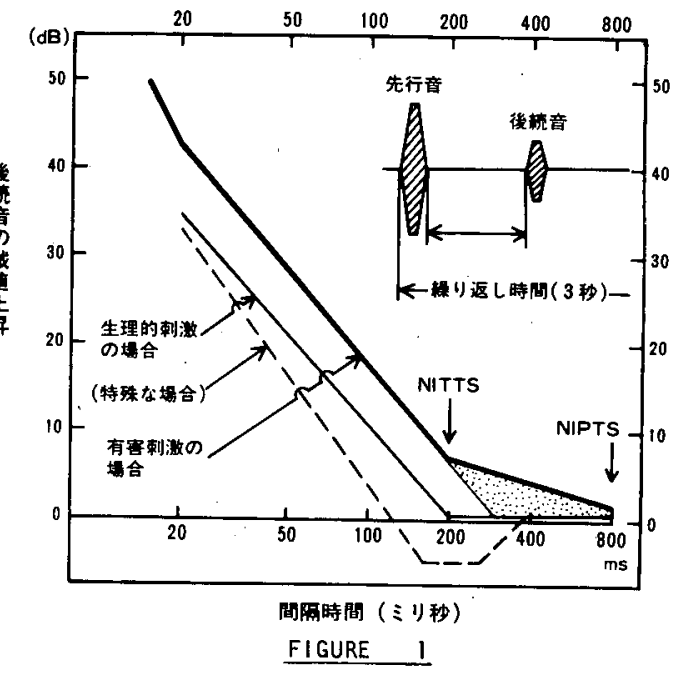

Forward Masking と云う現象は四1にも示したように先行にた音刺激による aftereffectとして 後続音の最小可聴值が間隔時間 200msec.以内で上开する現象々指すが、 この現象は先行音の性梖によりその経過に違いがめり先行刺敫が非生理的有害量に達 すると四中の太い実線の経過のように度労回復経過と似た2相性の回復曲線を示す。 このような回復経過をみせる先行音の刺激量を求めるのが测り方の原理である。すでに

騒音暴露と Foward Masking の時間的関係

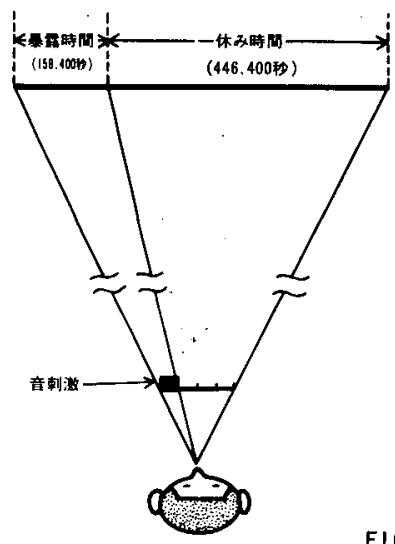

FIGURE $\quad 2$ 多くの柕音暴露実倹から知られているよう に、有害刺激音聴取下では域伯け刺激時 間の指数関数とはて上昗し、解放時にはま 時間の指数関数とにて 規則正1く回復 するから、1迪間の労仂生活时間の割合い とForward Masking の経過時間を四2のよ うに対応させてみた。作業假説として騒音 下実生活を60万分の1縮尺门てみると、 NITTS ( 2 分後の TTS 値), NIPTS ( 16 時間経過

Forward Masking

(昀1 秒)

後のTTS値) 弚れぞれ図1に示すように 間䚛時間 $200 \mathrm{msec}$. および $800 \mathrm{msec}$. 時点で の第2音の域値に相当することになる。 今回、対象として健常耳亩㟟び、測定は この種の实鈋I便利な MULTI-DIMENSIONAL AUDIOMETER NA 301B(NAGASHIMA)お゙び同付屈イヤホ ン(TDH-39) 8用い，1)短音によ了域值の测定，2)臨界域揊 (ECB; 正常耳では1/3 octave 
band width に近い)を算出、3)第 1 音の有害 刺激量 (power level)を求め、4)これと等価 ケ1オフターブバンドの騷音レベル(dB(A)) を求め測定音域全体の虱音レベルを積算 iた.

\section{3. 研究結果のきとめ.}

主厅知見のみを要約すると次のようである。

3.1. 耳小骨筋反射摡知のよう 潜伏 時間(50 150ms)。持続時間 $(900 \mathrm{sec})$ 、反応 しきい值 $(70$ - $90 \mathrm{~dB}(\mathrm{SPL}))$ 、回復時間( $0.5 \sim 3 \mathrm{sec})$ ともにかかっており Forward Maskingの第1 音の刺激時間の長さを：潜伏時間より短く するが長くするかによって、図3のよう に、同洱で2つの逴つた許容基隼をえる

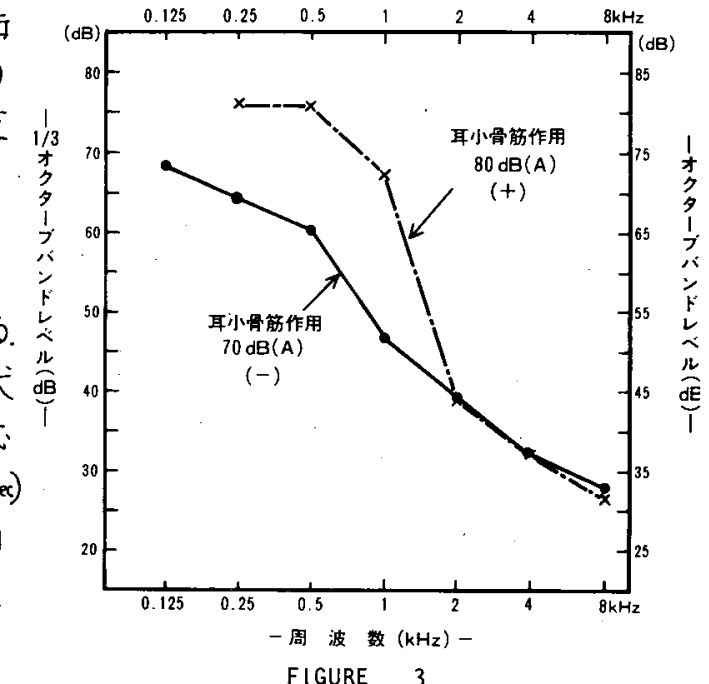

ことができる.

3:2. 先行音の剌激時間(実時間)が200msをえると それドけで有害刺激量となるから なるべく $100 \mathrm{~ms}$ 以内の先行音文侠用するのがよい，また、本法はこれまでの疲労試伢とくら ベて 1)繰り返に測定が可能で、2)暴露音による過

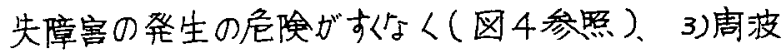
数别の許容基活の测定ができ、(が 4)短晆間で 済み、5)-つーつの耳についての記述ができる。な どの特长がみられる。

3.3. 騒音に:よ3聴罢障害の許容基準は 四3に示値 にトように最小基隼は70dB(A)と推测される。: 上 の值1ま partial noise exposure index(ISO-R1999,1971) の計算式 $E_{i}=\Delta t_{i} / 40 \cdot 10^{0.1\left(L_{i}-70\right)}$ の. 70 説明する数值 である。

3.4. この方法で得られたーつーつの耳での許容基 準值から 単発性のインパルス音に対する許容基渠 を equal energy conceptをつかつて推定することも できる。

3.5. この方法で之られア耳の音既受傷性㐜 想像

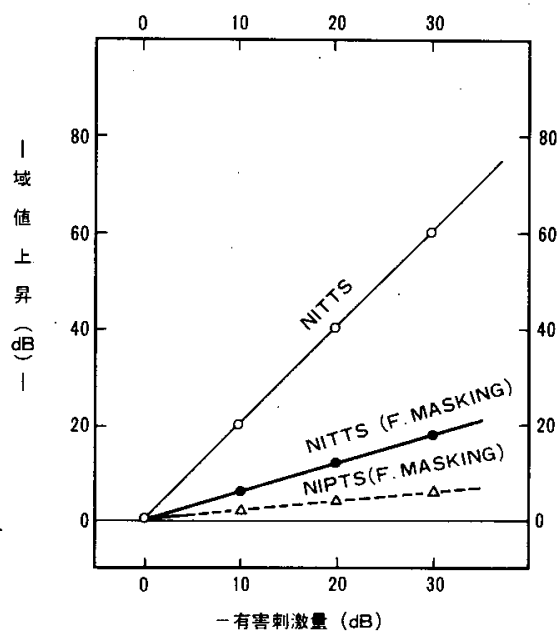

FIGURE $\quad 4$

していたよりも遥かに低く、一般的放令による聴力变化に都市騒音の影響も考之られる。

4. 参考文献.

1) KRYTER, K.D.( 1970 ):'The effects of noise on man. ',Academic Press, New York. 2)BURNS,W. (1973): 'Noise and man.', William Clowes \& Sons, London. 3) LITTLER,T.S. ( 1958 ): Ann. Occup. Hyg. 1,11. 4)平松義郎（1968）:Pract.0tol (Kyoto), Vol.61,1363-1396. 5)解原勇 $(1968$, Sept.) 内耳磁焦研究会詥文集，49-55. 